\title{
COMPARATIVE STUDY OF CHRISTIAN AND PAGAN BURIAL CONSTRUCTIONS
}

\author{
Eglè Bazaraité1 ${ }^{1}$, Teresa Heitor ${ }^{2}$ \\ ICIST, Instituto de Engenharia de Estruturas, Território e Construção, \\ Instituto Superior Técnico, Lisbon, Portugal \\ E-mails: ${ }^{1}$ egle.bazaraite@ist.utl.pt; ${ }^{2}$ teresa.heitor@ist.utl.pt
}

\begin{abstract}
This paper draws a chronological timeline comparing burial customs and construction traditions in the cradle of Christian religion, and pagan traditions on the Eastern coast of the Baltic Sea, precisely Lithuania, since the early ages of Christianity (1c. A.D.) until nowadays. This paper searches for reasons that could have effected cultural transformations, a shifting relation between inhumation and incineration in European culture. In the Ancient Roman culture, people used to cremate their dead before Christianity set in. Baltic pagans at the time were burying their dead in stone circles, and started incineration only during the Middle Ages. Then Christianity was a powerful institution indoctrinating European daily culture. Meanwhile, in the territory of Lithuania pagan culture was erased only in the $15^{\text {th }}$ century, i.e. about 600 years ago, leaving evident vestiges on traditions and customs of nowadays. These revelations of pagan culture are usually mistaken as Christian or Catholic. The paper focuses on architectural and urban aspects of burial architecture, taking into account social and historical conditions.
\end{abstract}

Keywords: cemetery, graveyard, funeral, pagan, Christian, inhumation, incineration, cremation.

\section{Introduction}

The study presents observations and chronological notes on burial traditions and constructions in two different corners of Europe - the Eastern Baltic coast, inhabited by the Aestian tribes, including a tribe that today is called Lithuanians, and the cradle of Christianity - the Mediterranean coast.

First and foremost it must be noted a very different urban development in these two areas. After the high civilization of Ancient Greece, it was the Roman Empire that was presenting itself as the most urban and organized development in Europe. In the beginning of the Roman Era in the $3^{\text {rd }}$ century B.C. no written information is found about the area on the Eastern coast of the Baltic Sea, where Lithuania is situated nowadays. It was Tacitus that mentioned Aestian tribes for the first time in history. Aestiorum gentes supposedly included all the tribes that inhabited that region, stretching up Northwards, up to the Gulf of Finland, and Southwards, reaching the region inhabited by Barbarians. Banyte-Rowell (2001: 29) mentions that historians and writers of Ancient Rome espied the Aestian tribes somewhere in the periphery of the Barbarian territory and didn't pay much attention to them, since Romans were more concerned with Barbarians. Such situation continued until the $10^{\text {th }}$ century when Lithuanian tribes by their political and territorial activities started playing a significant role in the history of Europe.
Traditions of the Aestian tribes and later Lithuanians were described and depicted much later than Roman traditions. Christian life was documented almost since its beginning; however pagan traditions can be only understood through archaeological research, recovering the vestiges of life at those times. Even after the Middle Ages the history of Lithuania continues with lack of iconographic information. For this reason, most of the burial examples from the Baltic region analyzed in this paper are taken from archaeological documents.

However Vaitkevicius (2011) claims that there was a common knowledge about the ancient religion of Baltics in the $19^{\text {th }}$ century countryside of Lithuania - the stories were told from one generation to another describing sacred places and rituals. This knowledge unconsciously arrived to our days, leaving identifiable traces in contemporary culture of Lithuania.

The paper focuses on the architectural and urban aspects of burial traditions that are evaluated in relation to religion, customs and traditions of Christianity and paganism, and the relationship between these two religions. The goal is to define the chronological transformation of constructions for inhumation and incineration since the birth of Christianity, showing the coalition of different beliefs, that today result in Catholicism with the vivid expressions of 
pagan culture. Oliveira (2007: 28) argues that coalition of Christianity with Judaism, resulting in the Christian burying traditions, was firstly constructed by adopting the doctrine of Judaism and later - by neglecting it. The same relation is common for most of European beliefs that existed during the Roman Empire and in later ages when Christianity was a leading religion in Europe. Based on this, the paper aims to look at the architectural burial constructions and reflect on how architecture reproduces religious beliefs.

\section{End of the iron age. \\ Early ages of christianity}

Speaking of burial traditions Banyte-Rowell (2001: 30) points out that practical and aesthetical matters are spread and shared easily by the ethnically and culturally different communities. However she considers that accepting a new custom is far more difficult. In her opinion, although burial rites were accepted not necessarily for material interest or aesthetical fascination, some common rituals and modes of burial constructions were (and still is) shared by distant cultures, which supposedly confirms the derivation of different ethnic groups from the same "ethnical trunk".

Many archaeological findings confirm that the Aestian tribes had been burying their dead in the stone circles (Banyte-Rowell 2001; Michelbertas 1994). The tradition might have started 500 B.C., when the stone constructions were already used for graves in barrows. Nevertheless the stone circles constructed between the $1^{\text {st }}$ and the $4^{\text {th }}$ centuries presented more organized structure and specific drawing. The archaeologists in Paragaudžio barrows found vestiges of rites with fire (Michelbertas 1994). These rites with fire were executed in some different ways. Some dead supposedly had been burnt however body cremation became common in the later stages of Baltic burial traditions and presented different structure of the grave. More common rites with fire at these times were "the charred remnants, cinders or ashes of the hearth or a simple fire were scattered in burial pits, fires were lit above the grave within a stone circle" (Banyte-Rowell 2003: 35).

Fire presents the same significance as stones in these burial traditions. They both function as magic frontiers that protect the dead from bad spirits protecting as well the living people from the buried dead. The symbolism of the stone circles can be analyzed in the context of the Sun cult or beliefs of eternal return inter alia (Michelbertas 1994: 15). There are important objects found together with the buried like pieces of horse body or horse equipment, as well as jewelry, clothing and work instruments. It is important to note these elements for possible understanding of the burial grave as a kind of abode for the after-life where these objects might be necessary. However a horse, especially in the later traditions, as archaeological researches conclude, is buried together with the master for fulfilling another role - a transportation of dead to the world of the afterlife.

At the same period, the Roman Empire was becoming Christian and occupied a significant territory in Europe. Most of the Christian beliefs of the time had adopted Judaic elements, mixed with beliefs of Ancient Greece and Rome (Oliveira 2007: 28). At that time, the Roman Empire didn't have almost any awareness what was happening behind the Barbarian tribes, settled in the North. Nevertheless the Baltic tribes still had some amber selling relations with the Roman Empire, and that brought some objects of Roman culture, identified in archaeological excavations of borrows - objects like jewelry or Roman coins (Michelbertas 1994: 21). Other cultural impact remains unknown.

It is obvious that at those times neither the traditions of Aestian tribes, nor the Roman ones could have supposedly affected each other for the reason of distance. Though basing on the idea of possible "same ethnical trunk", presented by Banyte-Rowell (2001: 30), it is important to juxtapose architectural customs of different cultures.

Romans were burying their dead in the city territory until 450 B.C. Following the Law of the 12 Tables burial houses were constructed along the access roads to Rome. These constructions had various floors, conical or circular plans, were with columns or pyramid-shaped (Oliveira 2007: 28). Dead bodies were burnt and aches were placed in urns, then the urns were kept in these structures outside the city. The size of the tomb represented the wealth of the family that at its best constructed a tomb of many rooms and had another building for burying slaves and freed slaves.

Since the Judaic tradition did not permit incineration of a dead body, the Judaic communities in Ancient Rome found a solution for burying - they secretly used former galleries of pozzolana extractions (Oliveira 2007: 30), where the holes were excavated in the walls for the inhumation of dead. First use of these galleries dates back to the $1^{\text {st }} \mathrm{c}$. A.D.; later they are used by the representatives of the new Christian religion. This points out an important change in the mode of funeral traditions that during the next 1000 years would spread through the whole Europe, including furthest pagan tribes.

\section{Incineration vs. inhumation}

While the Roman Empire was adopting Christian religion and leaving behind the traditions of incineration that was obviously changing the architectural expression of sepul- 
chers, the Aestian tribes started practicing incineration of the whole dead body. It was a transition from the rites with fire, adding ashes and burning fires around the dead body, to the total cremation.

It is interesting to note that using fire in funeral rites today might have derived from pagan fire rites held during the Iron Age (Banyte-Rowell 2003: 26) that continued into cremation during the second millennium and is still maintained nowadays through lighting candles in cemeteries in the Northern Europe. Banyte-Rowell (2003) points out similar semantic meaning of fire rites in Indian culture that has been analyzed by Beresnevicius (1993) as well.

During the $4^{\text {th }}-5^{\text {th }}$ centuries unburnt bodies were buried in pits under the barrows (Vaitkevičius 2005: 49). When the Aestian tribes started burning their dead in the $5^{\text {th }}$ century (Vaitkevičius 2005: 49), they continued their burying traditions involving stone constructions. Different stone constructions in this territory even help to identify different Aestian tribes. Some constructions were below the ground level, and in these cases there was no proof of architectural elements marking the grave position on the ground level, since they were covered with earth. The barrows included stone constructions inside as well. In these cases a little hill was the only topographic transformation of the burial territory. Such particularity of Aestian graves was contrary to the Roman architectural solutions, as they in the $1^{\text {st }}$ c. A.D. already constructed fancy memorials for burying their dead turning cemeteries into public places. At the time, still non-Christian Romans were still burning their dead. However Aestian pagans demonstrated a very different relation to the earth and death - dying is literally going back to nature and all surroundings when incinerated or inhumated. Vaitkevicius (2005) explains that the incineration tradition might had been started by soldiers.

Aestian pagans were holding their rituals in the sacred forests or by other sacred elements of nature. Starting with the $4^{\text {th }}$ century, Christian religion forbids cremation of the dead, because the body will still be necessary on the Last Judgment Day. Instead of the inhumation in catacombs, burying culture took another path: faithful believers wanted to be buried by the tombs of martyrs or locations of sacred events, where after some time churches were built to receive the faithful deceased, as well as to hold the mass (Oliveira 2007: 33). It was impossible, however, to keep all the dead inside the churches, so it was started to bury outside the church walls. This tradition of burying the church members and rich inside, while burying the poor by the church wall was maintained up to the $14^{\text {th }}$ century.
Christian culture had no interest in the Baltic tribes until the $10^{\text {th }}$ century - at that time all the Barbarians have been Christianized, and plans were made of Christianizing more people. At that time the Baltic tribes underwent one more transformation in their burial tradition: the $9^{\text {th }}$ century marked the beginning of cremation ritual. This mode of burying can be identified as one of the cornerstones of Lithuanian statehood and solidarity of different tribes that managed to maintain their culture in the forthcoming 400 years and extend their territory to the Black Sea.

Usually pagans were cremated in the place where they died (Girininkiene 2004: 7). The dead were burnt in the pyre constructed of big wooden logs that after burning were covered with ground creating a barrow. In the $13^{\text {th }}$ century the location of burning Lithuanian monarchs changed: it was held in one place - sacred pagan pyre place by the sacred forest where Vilnius is today.

Traditional interpretation of incineration customs in Lithuania in the $13^{\text {th }}-14^{\text {th }}$ centuries refers to the consciousness of statehood expressed for countering Christian religion. Luchtanas (2002: 158) doubts this hypothesis leaving the ideas of nationality for the $18^{\text {th }}$ century illuminists. He raises a question of why and how this context enabled the existence of these customs and what position was open for newly coming Christian ideologies in funeral practice.

It was a critical moment, when all the burying traditions in Lithuania were unified into one according to the law directed by Šventaragis (Girininkiene 2004: 26). There was still another important moment - that of transition from burying in the stone graves into using wooden coffins.

At this time the first coalitions of Christian and pagan cultures can be observed. The cremation in a pyre was traditional until the beginning of the $15^{\text {th }}$ century in the Baltic territories. Then Christian invasion started transforming the rites, nevertheless vestiges of pagan culture are maintained until nowadays considering them as Christian.

The Middle Ages in the Baltic territories are dated around the $13^{\text {th }}-15^{\text {th }}$ centuries. This aspect distinguishes the Baltic tribes from Roman society in many aspects, especially, as mentioned before, in terms of urban development and social lifestyle.

\section{Coalition of cultures}

First Christian cemeteries in Lithuanian territory appeared in the beginning of the $14^{\text {th }}$ century. These cemeteries were in Vilnius city. However, until the $16^{\text {th }}$ century Christianity in Lithuania was not rooted and did not have deep traditions in practicing faith and burying the dead. The old customs persisted - people continued to bury in old graveyards, 
situated on the hills, in the sacred groves or meads, usually close to the creeks or other water elements (Girininkiene 2004: 9). During the next two centuries Vilnius gained a reputation of a very religious city, full of churches of different confessions. Burying customs were similar to the rest of Christian Europe - people were buried in church and monastery cellars as well as ad sanctus - by the church wall where pipes dropped out the rainwater down off the church roof (Rekevicius 2008: 33).

Nevertheless another architectural case was developed in Europe, which in fact never had a chance to be adapted in Lithuanian context. It was burying in the expanded church territory, when there were too many corpses to be held in the church cellars and around the walls. This expansion was made by creating the charniers - arcades that received dead bodies of rich Christians. Their tombs were decorated by bones of the poor ones (Oliveira 2007: 35; Ariès 1982: 55). This space had another use as well - holding markets and fairs, receiving pilgrims and for mass celebrations. In times of Romanticism, it as well obtained an amorous walks of couples. At the time cemeteries had no plants or flowers, since the Church defined the use of vegetal elements as pagan tradition.

The $18^{\text {th }}$ century Lithuanian cemeteries got the influence of the same ideologies as the rest of European funeral culture. At the time cemeteries of different confessions in Vilnius city were located in the urban territory inside the city wall (Rekevicius 2008: 11). The situation changed, when hygienic doubts were publicly expressed raising a possible danger of cemeteries being located too close to the daily life, polluting air and water (Girininkiene 2004: 11). So, the cemeteries were closed and moved outside the city wall, or even further. However since it was impossible to take away all the vestiges of bodies buried during the centuries in Vilnius city, these territories were naturally occupied by future constructions, leaving the city a "fame" of being built on graveyards and cemeteries.

The case of Vilnius is not exceptional. At the time customary Christian burials close to the churches and places of martyrdom or sacred revelations were already forbidden in many Christian cities, giving a start to a new kind of burial traditions. Cemeteries left the city and found their places in natural environment reviving the image of Eden.

The $19^{\text {th }}$ century in Lithuania was dedicated to foundation of new cemeteries outside the city wall. Such established graveyards served different confessions: Catholic, Protestant, Orthodox, Jewish and Muslim. These confessions define well the image of the city at the time. Graveyards for victims of various epidemics, as well as orphans and other unlucky people were founded.

\section{Echoes of paganism}

When European Christian graveyards and cemeteries were revisiting the imaginary Eden described in the Bible, the Eastern coast of the Baltic Sea, precisely Lithuania, was recovering the tradition of sacred forests of paganism. Changing the location of the cemeteries, turning them into graveyards - landscape gardens has some very rational explanations that concern new ideologies of hygiene and corporal worries.

It was not only cemeteries that were banned from the $18^{\text {th }}$ century Christian city. Hygienic and moral reasons moved away from the city slaughterhouses, asylums and prisons. These city institutions were seen as impure (Oliveira 2007: 65). Though a body in Christian thinking had always been of a main concern, it was associated with two contradictory approaches. On the one hand, the body, as well as soul, was required to participate in the Final Judgment. On the other, the body had always been bound to such impurities as blood, sex, viscera, and sometimes racial and ethnical differences, taken as dirty. What is more, charnel houses were too full to continue receiving more corpses, science was opening new horizons and needed a new social platform for experiment and research that meant desacralizing the society, leaving behind the worries about the necessity of your own body after death. What is more, it was the age when atheism became more common, and surprisingly this change started another way of relation to the passed away. Ariès (1976: 72) points out that "from the end of the eighteenth century and even at the height of the nineteenth and twentieth centuries in anticlerical and agnostic France, unbelievers would be the most assiduous visitors to the tombs of their relatives".

The Catholic Church ended up assuming a new position and new relation to the funeral rites. Commercialized burying has been adapted to the religious actions, and in the $21^{\text {st }}$ century we are the witnesses of the mixed burial traditions, where religious beliefs, commerce and profanity cohabit.

The $20^{\text {th }}$ century has been very cruel for Lithuanian history. Rich in various events, it left the scratches on the country's culture that are difficult and almost impossible to recover. Some things have been lost forever. Cemetery and graveyard heritage is one of these unrecoverable elements in Lithuanian culture: many of them have been closed, buildings and roads constructed on top of them, leaving many people with the hard consciousness of living over the bones. It is a difficult condition for society with deep roots in paganism that disappeared less than 600 years ago - it is like navigating without original references of your own identity. 


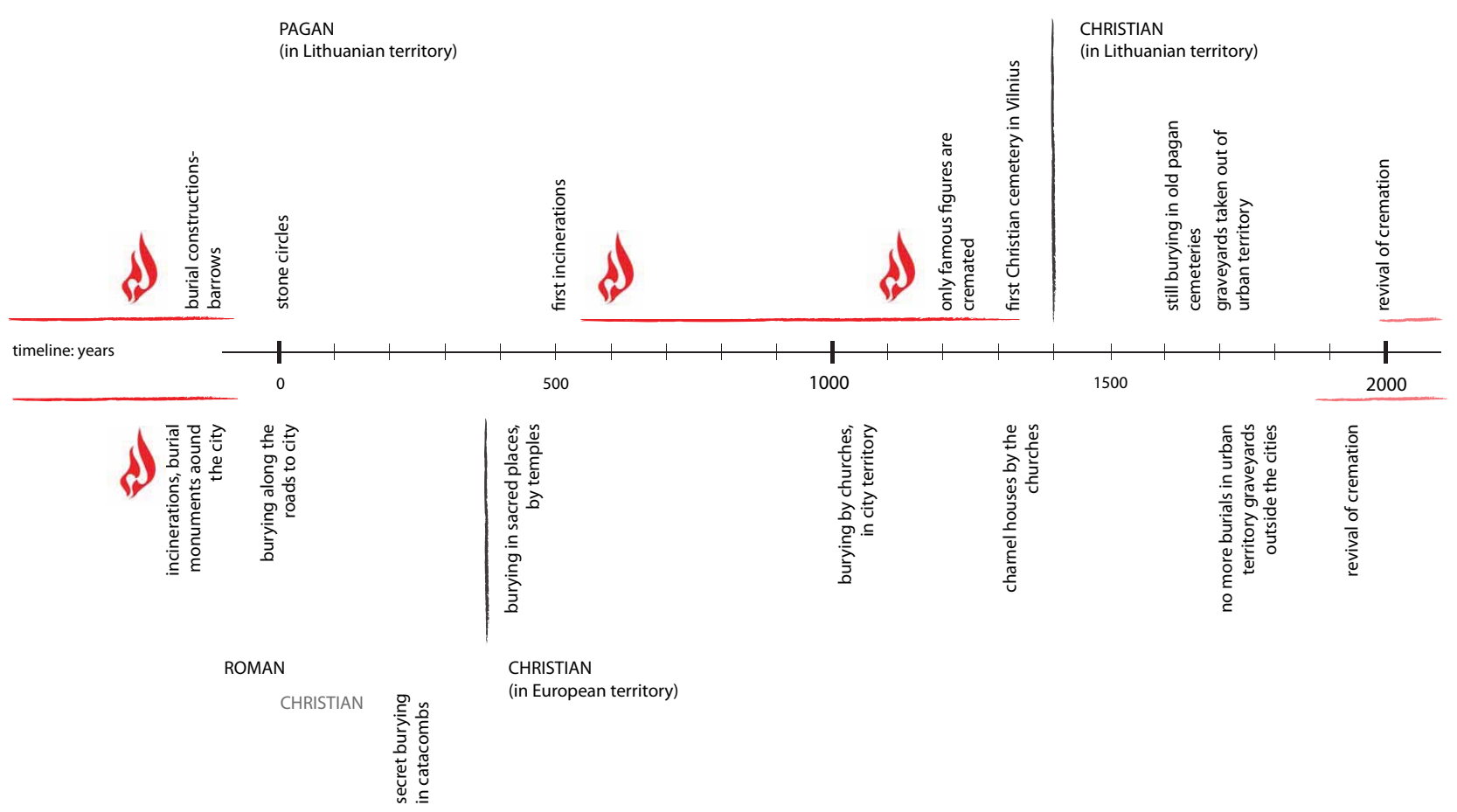

Fig. 1. Chronological timeline: Transformations of Pagan and Christian burial rites since the birth of Christianity

Lithuania during the $20^{\text {th }}$ century suffered various occupations followed by different ideologies. Attempts to create atheist graveyards didn't result as expected by the Soviet Union. Lithuanian graveyards are the examples of pagan and catholic traditions blended together, unable to expel the use of cross, vegetation, fire rites inter alia.

Since cemeteries were removed from the temple and city territory, in fact they came back to the traditional imagery of pagan culture. Lithuanian pagan traditions of burying on the hills and in the forests have been unconsciously revisited by modern graveyards of the $20^{\text {th }}$ century. The graves continue to be defined by the rectangular or square constructions in concrete or stone that might be unconscious contemporary interpretation of stone circles and rectangles from the Iron Age. Graves are full of flowers, and every visit brings a candle to celebrate pagan rites that survived until the $15^{\text {th }}$ century as a part of Lithuanian pagan culture.

\section{Conclusion}

This paper draws a chronological timeline of funeral traditions and constructions in two opposite poles of the European culture - Christian and pagan. Since early ages of Christianity, paganism had always been under the effort of survival giving its last breath in the $15^{\text {th }}$ century, when the last pagan country in Europe - Lithuania - was Christianized. Anyhow the echoes of this culture are still vivid in many social aspects.
The concept of "European ethnical trunk" suggests possible similarities of thought and posture of different burying traditions. Following a chronological timeline of burial architecture in the Aestian tribes, which later transformed into Lithuanians (stone circles - barrows in forests and meadows incineration and burial in forests and meadows - burying in the Christian church territory inside the city - burying outside the city in Christian graveyards in natural surroundings), we observe a return to the original burial concepts. This idea is supported by similar structures of tombs.

Christian burial traditions included incineration and burying intra muros, practiced by non-Christian Romans, then burying outside the city, while new Christian religion invented secret inhumation of unburnt corpses in catacombs. When Christian religion was legalized, corpses were buried intra muros in the church territory until the $18^{\text {th }}$ century, when hygienic reasons and ideas of Enlightenment found their place forcing the cemeteries out of the city, where they continue until now. Growing cities embrace these graveyards and make them part of the urban fabric again. Cremation appeared again in the beginning of the $20^{\text {th }}$ century, however Catholic countries disapprove this rite for doctrinal reasons.

Cemeteries and graveyards today, after a long history of transformation, are at the point of return to the ancient rites (burying in the forests/natural surroundings, cremating etc.). These rites that have come from the relation to the natural world might be more appropriate 
for agnostics of the $21^{\text {st }}$ century, just like they were for the $18^{\text {th }}$ century intelligentsia that marked a great turn in the burial culture.

Return to these rites means rethinking a position of architecture and urbanism in a contemporary city.

\section{References}

Ariès, P. 2009. Western Attitudes toward Death: from the Middle Ages to the Present. London: Marion Boyars Publishers.

Ariès, P. 1982. The Hour of Our Death. New York: Vintage Books.

Banytè-Rowell, R. 2001. Vakaru Lietuvos kapinynų laidosenos ypatumai vėlyvuoju romėniškuoju laikotarpiu, Archeologia Lituana 2.

Banytė-Rowell, R. 2003. Aistiškosios laidojimo apeigos Lietuvos pajūryje lyginamosios religijotyros kontekste, Lituanistika 1(53): 24-36.

Beresnevičius, G. 1993. Senovès lietuvių sielos sampratos metmenys: siela ir gamtos elementai, Liaudies kultūra ${ }^{\circ} 1$.

Girininkienè, V. 2004. Vilniaus kapinès. Vilnius: Atkula.

Luchtanas, A.: Vèlius, G. 2002. Valstybès gimimas ir mirusiuju deginimo paprotys, in Archeologia Lituana, 157-161.

Michelbertas, M. 1994. Šilalès kraštas. Vilnius: Lietuvos kraštotyros draugija

Oliveira, M. M. L. P. de. 2007. In memoriam, na cidade. Universidade do Minho.

Rekevičius, L. 2008. The Historical Place of Confessional Districts in the Structure of City Vilnius. Vilniaus Gedimino technikos universitetas.

Vaitkevičius, V.; Kurila, L. 2011. Mirusiųjų deginimo papročio reflekcijos: padavimas apie Migonių piliakalnị, Tautosakos darbai XLI: 107-134.

Vaitkevičius, V. 2005. Vienos teorijos pėdsakais, arba mirusiųu deginimo paprotys Rytu Lietuvoje, Lietuvos archeologija 27: 49-58.

\section{PAGONIŠKŲJŲ IR KRIKŠČIONIŠKŲJŲ LAIDOJIMO KONSTRUKCIJŲ LYGINAMOJI STUDIJA}

\section{E. Bazaraitė, T. Heitor}

\section{Santrauka}

Straipsnyje sugretinami pagoniškieji ir krikščioniškieji laidojimo ritualai ir architektūrinès konstrukcijos. Remiantis istoriniais duomenimis, akivaizdu, kad krikščionybès išplitimas padare ịtaką pagoniškųjų kraštų laidojimo ritualams ir architektūrinei išraiškai. Akivaizdu ir tai, kad pagonybè taip pat paliko pėdsakus krikščioniškoje kultūroje. Organiškas šių skirtingų kultūru elementų santykis yra ilgo kultūrų gretinimo pavyzdys. Lietuvos teritorijoje pagoniškosios kultūros liekanų itin gausu. Straipsnyje chronologiškai apžvelgiama, kaip kito laidojimo ritualai Lietuvos teritorijoje ir koks jų santykis su laidojimo tradicijomis krikščioniškosios kultūros lopšyje, apimančiame seniausius krikščioniškuosius kraštus. Ieškoma priežasčių, kodèl vienos ar kitos laidojimo konstrukcijos kito, koks jų ryšys su miesto teritorija ir kontekstu apskritai.

Reikšminiai žodžiai: kapinès, laidojimas, pagoniškieji, krikščioniškieji, kremavimas, kapinių architektūra. 